\title{
Böbrek fonksiyonlarına göre sakubitril/valsartan yönetimi nasıl yapılmalıdır?
}

\author{
Dr. Ahmet Temizhan, Dr. Mustafa Arıcı \\ Sağlık Bilimleri Üniversitesi, Ankara Şehir Hastanesi, Kardiyoloji Anabilim Dalı, Ankara
}

Kronik kalp yetersizliği (KY) hastalarında neredeyse kaçınılmaz olan böbrek fonksiyon bozukluğu kötü prognozun güçlü bir göstergesidir. ${ }^{[1]} \mathrm{Bu}$ sürecin yönetilmesi yakın ve multidisipliner takip gerektirir. Böbrek fonksiyonlarında bozulma oluncaya kadar KY hastasında renin anjiotensin aldosteron sistem (RAAS) bloker tedavisini yönetmek kısmen kolaydır. Ancak bu dönemde RAAS blokerlerinin hedef dozlara çıkılmadığının, başlanan düşük dozlara çoğu hastada miras gibi devam edildiğinin altını çizmek isteriz. Tolere edilebilen en yüksek doza (en azından hedef dozun $\geq \% 50$ 'si) çıkılması düşük EF KY (dEFKY) hastalarında RAAS blokerlerinden beklenen mortalite ve morbidite azalmasını sağlamak için elzemdir. ${ }^{[2]}$ Böbrek fonksiyonları bozuk olan hastalarda RAAS blokerlerinin yönetimini öğrenmek için önce stabil gibi gördüğümüz KY hastalarında doz artımı konusunda daha çok çaba sarf etmeyi tecrübe etmemiz gereklidir.

Anjiyotesin dönüştürücü enzim inhibitörü/anjiyotensin reseptör blokerinin (ACEI/ARB) doz artımı ile gelişen serum kreatinindeki artış çoğu zaman bundan vazgeçilmesiyle veya ilacın kesilmesiyle son bulmaktadır. ${ }^{[3]}$ Kronik böbrek hastalığ 1 (KBH) olan dEFKY hastalarında daha sık görülen bu atalet ACEI/ARB ile sağlanacak mutlak risk azalmasından, ki fayda görme ihtimalleri daha yüksektir, hastaları mahrum bırakmaktadır. ${ }^{[4]}$

PARADIGM HF çalışmasında sakubitril/valsartan (SV) kullanan dEFKY hastalarında enalaprile kıyasla ikincil sonlanım olan böbrek fonksiyonlarında bozulma [son dönem böbrek hastalığ veya tahmini glomerüler filtrasyon hizı (tGFR) $\geq \% 50$ azalma veya randomizasyondan sonra $>30 \mathrm{~mL} / \mathrm{dk} / 1.73 \mathrm{~m}^{2}$ azalarak $60 \mathrm{~mL} /$ $\mathrm{dk} / 1.73 \mathrm{~m}^{2}$ altına düşmesi] sıklığı daha az görülmüsstür (\%2.2-\%2.6, $0.86 \% 95 \mathrm{GA} ; 0.65-1.12, \mathrm{p}=0.28)$. İstatistiksel anlamlı düzeye ulaşmasa da SV ile daha fazla hipotansiyon gelişmesine rağmen elde edilen bu sonuç dikkat çekicidir. ${ }^{[5]}$ SV'ın dEFKY hastalarındaki renal etkilerini PARADIGM HF çalışması üzerinden yapılan diğer analizler ile şu şekilde özetleyebiliriz;

1. Mineralokortikoid reseptör blokeri (MRA) kullanan ve SV'a randomize edilen hastalarda ciddi hiperkalemi (potasyum düzeyi $>6.0 \mathrm{mEq} / \mathrm{L}$ ) enalapril verilenlere kıyasla daha az gelişmiştir (HO, $1.37 \% 95$ GA; 1.06-1.76, $\mathrm{p}=0.02){ }^{[6]}$

2. Diyabet varlığına göre bakıldığında SV enalaprile kıyasla diyabetiklerde daha belirgin olmak üzere tGFR değerindeki senelik düşüş oranını yaklaşık $\% 50$ azalmıştır (fark $0.4 \mathrm{~mL} / \mathrm{dk} / 1.73 \mathrm{~m}^{2} / \mathrm{y} 1 \mathrm{l}, \% 95$ GA 0.3-0.6; $\mathrm{p}<0.0001)$. Ayrica tGFR üzerine etkinin KYnin nedeninden, ciddiyetinden, kan basıncındaki değişimden ve glisemik kontrolden bağımsız olduğu görülmüştür. ${ }^{[7]}$

3. Daman ve ark. önceden belirlenmiş alt gruplarda $\mathrm{KBH}$ olan (tGFR $<60 \mathrm{ml} / \mathrm{dk} / 1.73 \mathrm{~m}^{2}$ ) ve olmayan - SV'ın birincil sonlanıma etkisini analiz etmiştir. ${ }^{[8]}$ Bu çalışmadaki bir diğer amaç SV'ın tGFR'deki azalmanın yavaşlamasına enalaprilden daha üstün etkisinin olup olmadığını test etmektir. Renal sonlanımlara birleşik olarak "tGFR' de $\geq \% 50$ azalma ve son dönem böbrek hastalığı" tanımını da ekleyerek ayrıca post hoc bir analiz de yapmışlardır. $\mathrm{Bu}$ çalışmaların sonuçlarına göre;

- tGFR'deki senelik düşüş oranı SV ile enalaprile kıyasla daha az olmuştur $(-1.61 \mathrm{~mL} / \mathrm{dk} / 1.73$ $\mathrm{m}^{2} / \mathrm{y} 1 \mathrm{l}$ ve $\left.-2.04 \mathrm{ml} / \mathrm{dk} / 1.73 \mathrm{~m}^{2} / \mathrm{yll} ; \mathrm{p}<0.001\right) . \mathrm{Bu}$ bulgu KBH olan ve olmayan hastalarda benzerdir.

- Önceden belirlenmiş renal sonlanımlarda (yukarıda belirtilen), fark görülmese de post hoc analize katılan birleşik renal sonlanım (tGFR'de $\geq \% 50$ azalma ve son dönem böbrek hastalığg) SV verilenlerde daha az sıklıkta gelişmiştir (HO: 0.63; \%95GA: 0.42-0.95; p=0.028). Bu bulgu $\mathrm{KBH}$ olan ve olmayan hastalarda benzerdir. 
- SV verilenlerde üriner albumin kreatinin oranı (UAKO) daha fazla artmıştır $(1.20 \mathrm{mg} /$ mmol [\%95 GA: $1.04-1.36 \mathrm{mg} / \mathrm{mmol}$ ] ve 0.90 $\mathrm{mg} / \mathrm{mmol}$ [\%95 GA: $0.77-1.03 \mathrm{mg} / \mathrm{mmol}$; $\mathrm{p}<0.001)$. UAKO'deki akut artış tedavinin birkaç hafta sonrasında stabilize olmuş; devamında 1-8 ay benzer düzeyde seyretmiştir. Proteinürinin muhtemelen natriüretik peptitlerin (ve neprilisin ile katalize olan diğ er vazoaktif maddelerin) akut intrarenal hemodinamik etkisinden (glomerüler endotelyal geçirgenliğin ve hidrolik iletkenliğin artması) kaynaklandığ $\mathrm{nI}^{[9,10]}$ ileri sürmüşlerdir.

- Enalaprile kiyasla SV KBH olan ve olmayanlarda kardiyovasküler sonlanımlarda benzer oranda relatif risk azalması sağlamıştır (GFR $30-60 \mathrm{ml} / \mathrm{dk} / 1.73 \mathrm{~m}^{2}$ olanlarda 0.79, GFR $\geq 60$ $\mathrm{ml} / \mathrm{dk} / 1.73 \mathrm{~m}^{2}$ olanlarda 0.81$)$. SV'1n gerek kardiyovasküler sonlanımlara olumlu etkileri gerekse de tGFR' deki düşüşü azaltması $\mathrm{KBH}$ 'dan bağımsız olarak, kan basıncında daha fazla düşüşe ve UAKO'deki artışa rağmen elde edilmiştir. Enalapril ile tedavi edilenlerde UAKO'daki artış daha kötü renal sonlanımlar ile ilişkili iken SV'da böyle olmamıştır.

- İlacın renal olumsuz etkiler nedeniyle kesilmesi SV grubunda daha az olmuştur (HO: 0.49; \%95 GA: 0.31-0.76; $\mathrm{p}=0.002$ ).

SV kardiyovasküler olumlu etkilerinin yanı sıra renal etkileriyle de $\mathrm{KBH}$ olan dEFKY hastaları için önemli bir tedavi seçeneği olabilir. Burada klinik pratiğimiz için yapacağımız öneriler tedavi sırasında böbrek fonksiyonları bozulanlar ve bazalde KBH (30-60 $\mathrm{ml} / \mathrm{dk} / 1.73 \mathrm{~m}^{2}$ ) olan dEFKY hastalarını içermektedir (Şekil 1). Kidney Disease Improving Global Outcomes (KDIGO) k1lavuzu GFR $<60 \mathrm{~mL} / \mathrm{dk} / 1.73 \mathrm{~m}^{2}$ olan hastalarda araya giren ve akut böbrek hasarı riskini artıran ciddi bir hastalık durumu olmadığ 1 sürece ACEI// ARB tedavisinin kesilmemesini hatta GFR $<30 \mathrm{ml} /$ $\mathrm{dk} / 1.73 \mathrm{~m}^{2}$ olanlarda bile nefroprotektif etkileri nedeniyle bu ilaçlara devam edilmesini tavsiye etmiştir. ${ }^{[1]}$ KDIGO SV'na yönelik ek bir öneride bulunmamış, içeriğindeki ARB nedeniyle ACEİ/ARB'ler ile benzer yaklaşımları tavsiye etmiştir. ${ }^{[12]}$ Serum kreatinin artıŞ1 veya GFR düşüşü ACEİ/ARB (ve SV) için beklenen bir “yanetki"dir. Tedavi ile KYnde GFR' de erken bir azalma olsa da zamanla stabilize olmaktadır. Bu azalma son yıllarda "yalancı böbrek fonksiyon kötüleşmesi" olarak adlandırılmaktadır; çünkü bu durum böbrek hasarı anlamına gelmemektedir. Nitekim ge- nellikle doz azaltmak veya ilaca ara verilmek ile GFR düzelmektedir. Bununla birlikte, özellikle böbrek hastalarında ACEI/ARB ile serum kreatinindeki \%30'a kadar olan akut artış (sonrasında stabilize oluyorsa) böbreklerde koruyucu etki yapacaklarına dair bir göstergedir. ${ }^{[11]}$

KY hastalarının takibinde böbrek fonksiyon testleri sıç̧a kullanılsa da testlerin yorumlanması ve nasıl müdahale edileceği konusunda belirsizlik hakimdir. Serum kreatinin ve tGFR değerleri böbrek fonksiyonlarını yansıtmada çoğu zaman yeterli olamamaktadır. Bütün kısıtlılıklarına rağmen ESC Kardiyo-Renal Çalışma Grubu, bazal değerlendirme için kalp yetmezliği hastalarında CKD-EPI formülünü önermektedir. ${ }^{[13]}$ Sistatin-C düzeyleri kreatinindeki değişkenliği yorumlarken katkı sağlayabilse de hala gerçek böbrek hasarını gösterebilecek biyolojik ve fonksiyonel belirteçlere ihtiyaç duyulmaktadır. ${ }^{[12]}$ Bu nedenle SV tedavisinin yönetimi (RAAS blokerleri için de geçerlidir) sadece laboratuvar testlerine göre değil aynı zamanda hastanın semptom ve bulgularını da içeren yakın klinik takip ile yapılmalıdır. Hastanın semptomatik iyileşmesi gerçekleşiyorsa (nörohormonal aktivasyonun bastırılması ve konjesyonun azaltılması gibi), böyle durumda "yalancı böbrek fonksiyon kötüleşmesi" olmasından korkulmamalı; hastaların böbrek fonksiyonları da salt kreatinin veya tGFR ile değil, önemli böbrek hasarı göstergeleri (örn. hiperkalemi, asidoz vb) ile izlenmelidir. Bu tedavi sürecinde amacımız KBH'1 olan veya takibinde böbrek fonksiyonları bozulan dEFKY hastalarını iyi yöneterek hastaları tedaviden mahrum bırakmamak ve SV'nı mümkün olduğunca vermeye çalışmak olmalıdır.

Temel kurallar;

1. SV'ın kontrendike olduğu durumlar

- Anjioödem öyküsü

- Bilinen bilateral renal arter stenozu

- Gebelik/gebelik riski

- Bilinen alerjik reaksiyon/diğer yan etkiler (ilaca spresifik)

2. İlaç başlanırken dikkatli olunması gereken durumlar (uzman görüşü ve yakın takip imkanı varsa):

- Hiperkalemi $\left(\mathrm{K}^{+}>5 \mathrm{mmol} / \mathrm{L}\right)$

- Renal disfonksiyon (kreatinin $>2.5 \mathrm{mg} / \mathrm{dL}$ veya eGFR $<30 \mathrm{ml} / \mathrm{dk} / 1.73 \mathrm{~m}^{2}$ )

- ACEİ/ARB kullanırken semptomatik veya ciddi asemptomatik hipotansiyon (sistolik kan basinc1 $<95 \mathrm{mmHg}$ ). 


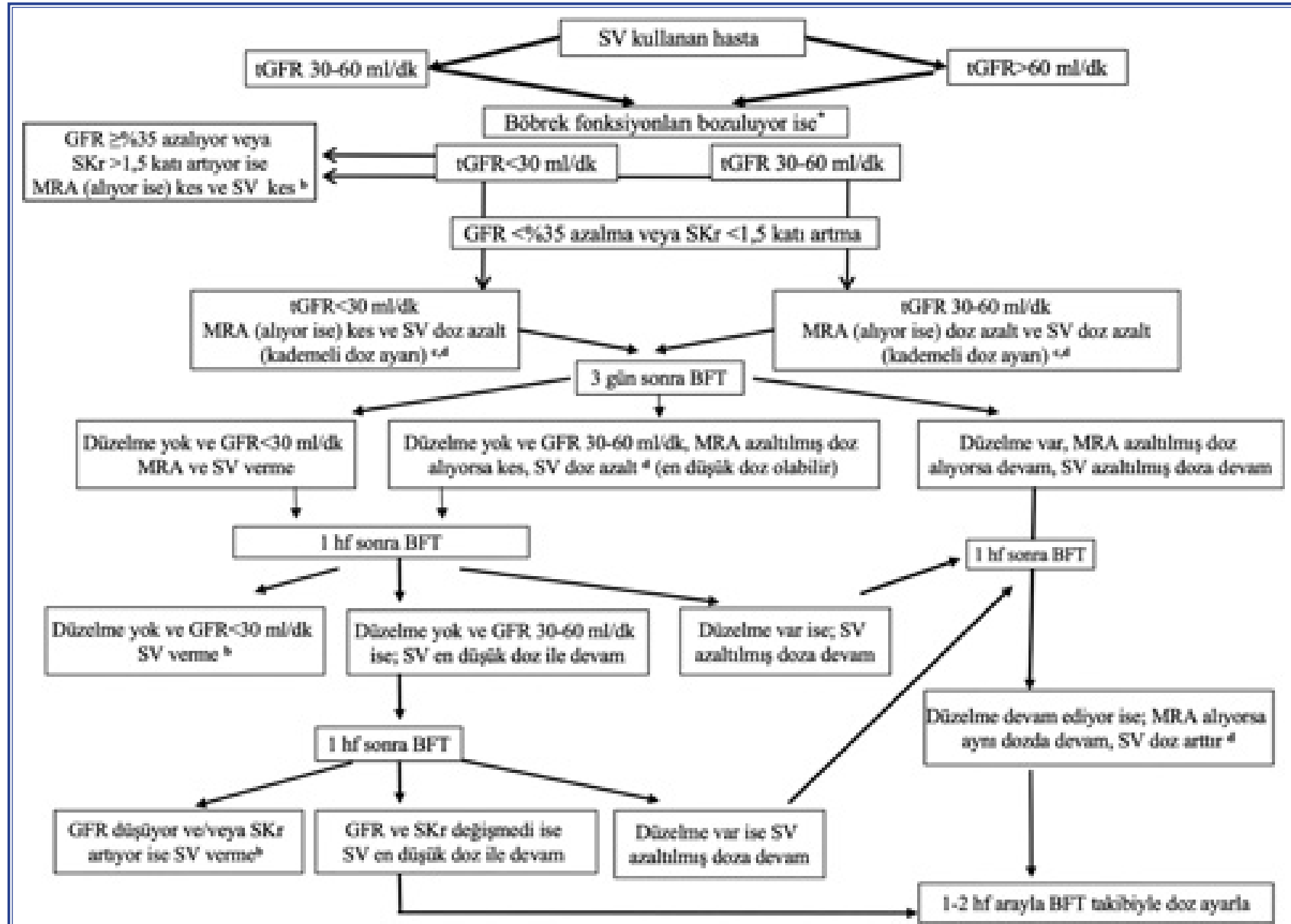

Şekil 1. Sacubitril/valsartan kullanan hastalarda böbrek fonksiyonlarında gelişen değişime göre doz ayarlama yaklaşımı.

*: Bu önerileri ambulatuar hastalarda uygulayabilmeniz için hasta ve yakınının tedaviye uyumlu olması gerekir. Aksi taktirde hastayı yatırarak izlemini yapmanız daha doğrudur.

SV: Sacubitril/valsartan; MRA: Mineralokortikoid reseptör antagonisti; tGFR: Tahmini glomerüler filtrasyon hızı; Skr: Serum kreaitinin; BFT: Serum böbrek fonksiyon testleri.

a: Hipotansiyon, sıvı kaybı, enfeksiyon ve böbrek fonksiyonlarına etki edebilecek diğer ilaçları (diüretikler, nonsteroid antiinflamatuar vs) gözden geçir. Hasta ve hasta yakını uyumlu ise ayaktan yakın takip yapılabilir ancak uyumun sağlanamadığı hastaları, konjesyonu olanları, fonksiyonel kapasitesi azalmış hastaları hastaneye yatırarak izlemek gerekir.

b: Akut böbrek hasarı ve/veya akut böbrek hastalığı düşünülmelidir, nefroloji görüşü alınmalıdır.

c: Sistemik konjesyonu var ise böbrek fonksiyonları diüretik tedaviden fayda görebilir, inotrop ihtiyacı olabilir, hastaneye yatırarak izlenmelidir.

d: Kademeli doz ayarı; Sacubitril/valsartan dozu artırılırken veya azaltırken ilk planda sabah düşük dozun akşam bir yüksek dozun verilmesi ikinci planda düşük dozun (veya yüksek dozun) sabah akşam verilmesi şeklinde uygulanır.

3. Böbrek fonksiyonları değerlendirilirken stabil hastalarda GFR (CKD-EPI formülü ile ama kisitlılıkların1 akılda tutarak), dekompanse KY ve/veya yoğun diüretik tedavisi uygulanan hastalarda sadece serum kreatinin kullanılır. ${ }^{[14]}$

4. Böbrek fonksiyonları bozulduğunda ilk olarak hipotansiyon, sıvı kaybı, enfeksiyon ve böbrek fonksiyonlarına etki edebilecek diğer ilaçları (diüretikler, nonsteroid antiinflamatuar vs) gözden geçirmek gerekir. Çoğu hastada ihtiyacı olmadığı halde kullanılan diüretikler böbrek fonksiyon bozukluğundan sorumlu olmaktadır. Ancak sistemik konjesyonu olan hastalarda akılcı diüretik kullanımı ile böbrek fonksiyonlarında düzelme sağlanabileceği unutulmamalıdır. Bu hastalarda dekonjesyonu sağlarken "yalancı böbrek fonksiyon bozukluğu" nedeni ile diüretik tedaviye ara verilmemelidir. Hipotansiyon ciddi ve semptomatik ise böbrek fonksiyonlarından bağımsız olarak ilaç doz ayarlamalarını gerektirir.

5. RAAS blokerleri ile serum kreatininde $\% 30$ oranında artış olabilir. Serum kreatinin değeri 48 saat içerisinde $\geq 0.3 \mathrm{mg} / \mathrm{dL}$ veya bazal değerin $1.5-1.9$ katı artıyorsa veya idrar miktarı azalıyorsa (alt1 


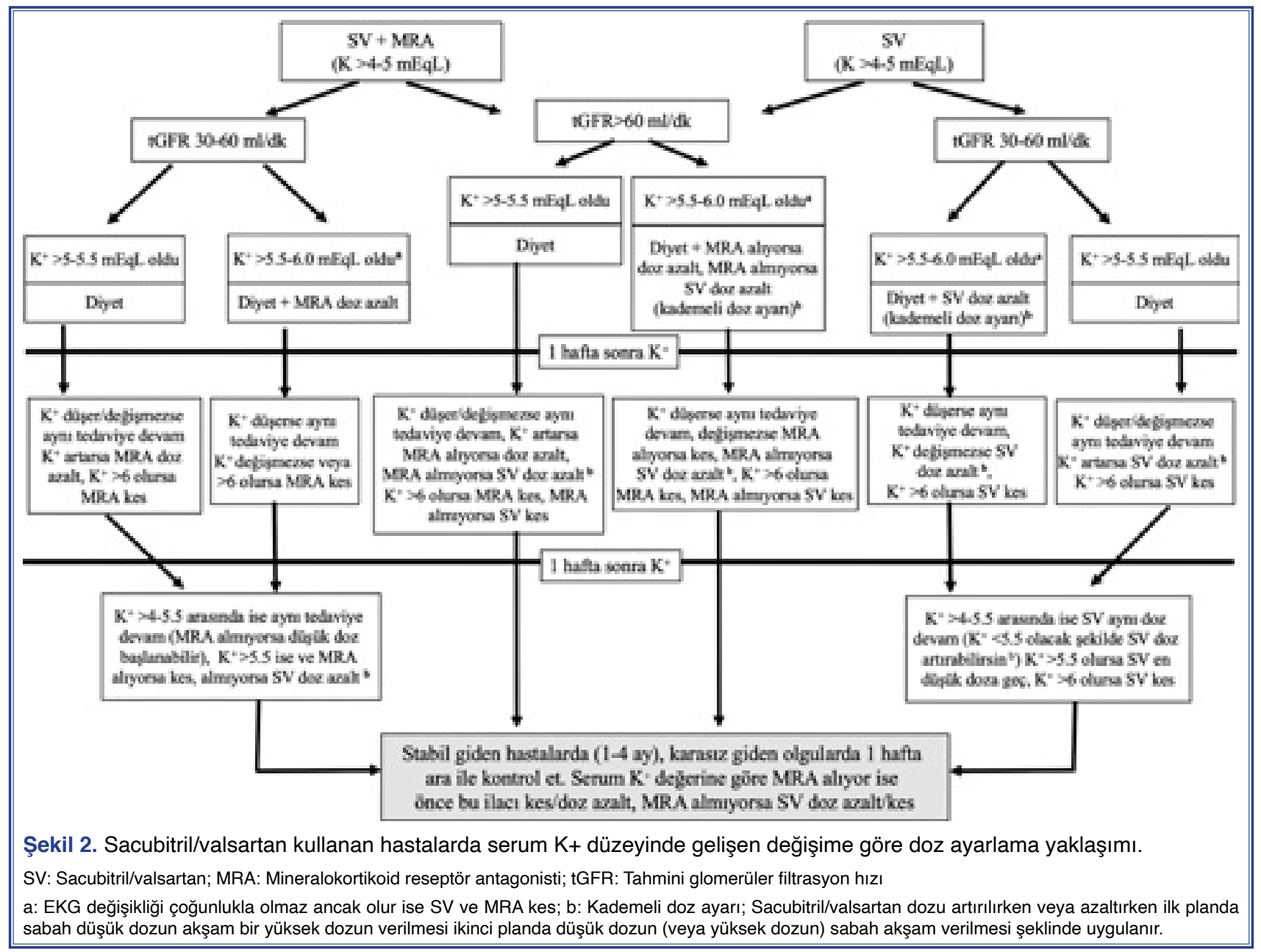

saatten uzun süre idrar miktarının $<0.5 \mathrm{~mL} / \mathrm{kg}$ / saat olması) ilaca bağlı akut böbrek hasarı oluşmuştur. ${ }^{[15]} \mathrm{Bu}$ tür bir durumda hastanın elde ettiği fayda ile zarar olasılığı değerlendirilmeli, kardiyak fonksiyonlar ve semptomlardaki iyileşme ile böbrek hasarındaki artış ihtimali yakın izlem ile değerlendirilmelidir. Hastanın sağ kalımında belirleyici rolün kardiyak fonksiyonların iyileşmesi olması unutulmamalı; böbrek hasarının ise yakın izlem ile artmasına mani olmaya çalışılmalıdır. $\mathrm{Bu}$ tür hastaların tek tek vaka bazlı değerlendirilmesi ve kardiyolog-nefrolog işbirliği ile yönetilmesi oldukça yararlı olacaktır.

6. Tedavi başlanırken ve/veya doz ayarlaması yaparken tGFR değeri $\geq 30-60 \mathrm{ml} / \mathrm{dk}$ olanlarda 3 günde bir, $>60 \mathrm{ml} / \mathrm{dk}$ olanlarda ise 2 haftada bir böbrek fonksiyonlarına bakmak çoğunlukla yeterlidir. Stabil giden GFR $>60 \mathrm{ml} / \mathrm{dk}$ hastalarda böbrek fonksiyon testleri genellikle 4 ayda bir tekrarlanır. ${ }^{[3,16]}$
7. Serum potasyum düzeyi $4 \mathrm{mEq} / \mathrm{L}$ üzerinde tutulmalıdır. Serum potasyum düzeyi $4.0-5.5 \mathrm{mEq} / \mathrm{L}$ aralığında olduğu sürece RAAS blokerlerine devam edilebilir. ${ }^{[17]}$ Ancak serum potasyumu $>5-5.5$ $\mathrm{mEq} / \mathrm{L}$ aralığında, özellikle diyabetik ve/veya böbrek disfonksiyonu olan hastalarda yakın takip yapılması şarttır. Düzenli takip yapılan hastalarda ciddi hiperkalemi gelişme ihtimali azalmaktadır. ${ }^{[18]}$ Kronik böbrek hastalarında ACEİ/ARB ve spironolakton ile birlikte kullanılan yeni potasyum bağlayıcılarının hiperkalemi gelişimini azaltması bu hastaların tedavi yönetimi için umut verici olmuştur. ${ }^{[19]}$

SV kullanılmakta iken GFR $\geq \% 35$ azalıyor veya serum kreatinini $>1.5$ katı artıyor ise akut böbrek hasarı ve/veya akut böbrek hastalığı düşünülmeli, SV ve MRA'nın kesilmesi düşünülmelidir. GFR <\%35 azaliyor ve/veya serum kreatinini $<1.5$ katı artıyorsa bazal ve güncel GFR değerine göre değişen sürelerde hastanın böbrek fonksiyonları takip edilir ve kli- 
nik bulguları da dikkate alınarak ilaç doz ayarlaması yapılır (Şekil 1). Hasta SV yanı sıra MRA alıyor ise önce MRA'nın dozunun azaltılmasi/kesilmesi uygundur. SV doz azaltımı ikinci aşamada düşünülmelidir. SV dozu artırılırken veya azaltılırken ilk planda sabah düşük dozun akşam bir yüksek dozun verilmesi, ikinci planda düşük dozun (veya yüksek dozun) sabah akşam verilmesi şeklinde kademeli yaklaşım başarı ihtimalini artıran pratik bir uygulamadır. ${ }^{[20]}$

Serum potasyumu her ne kadar böbrek fonksiyonlarından etkilense de bazen orantısız yükselebilmesi nedeniyle potasyum düzeyine göre SV yönetimi ayrı bir akış şemasında ele alınmıştır (Şekil 2). Klinik pratikte serum $\mathrm{K}$ değeri $>5 \mathrm{mEq} / \mathrm{L}$ olduğunda RAAS blokerlerinin kesildiği görülmektedir. Oysaki K > 5.5-6.5 $\mathrm{mEq} / \mathrm{L}$ aralığında EKG değişikliği eşlik etmiyorsa hiperkaleminin zararlı olduğu kesin gösterilememiştir. Dolayısıyla K >5-5.5 mEq/L arasındaki değerlerde tedavi iyi yönetilirse hem hasta güvende olacak ${ }^{[17]}$ hem de fayda göreceği SV (ve RAAS blokerleri) tedavisine devam edilebilecektir. Serum K >5-5.5 mEq/L aralığında, ilk planda nonsteroid antiinflamatuarlar, potasyum tutucu diüretikler, tuz eşdeğerlerinin kesilmesi ve sağlıklı olduğu düşünülerek sıkça tüketilen potasyumdan zengin gidaların (Bkz. National Kidney Foundation web sayfas1, http://www.kidney.org/ ATOZ/atozItem.cfm) azaltılması gerekir. Bunun yetersiz geldiği durumlarda öncelikle MRA dozunun azaltılmasi/kesilmesi, ikinci aşamada ise SV dozunun azaltılması (kademeli olarak) düşünülmelidir. Serum $\mathrm{K}>5.5-6.0 \mathrm{mEq} / \mathrm{L}$ aralığında böbrek fonksiyonları da dikkate alınarak diyet ile birlikte ilaç doz azaltışı kademeli bir şekilde yapılır. Serum K düzeyinde düzelme olması ve sebat etmesi halinde ilaçların (SV ile başlayarak), tekrardan tolere edebileceği dozlara yükseltilmeye çalışılması uygun olacaktır.

GFR değeri $<30 \mathrm{ml} / \mathrm{dk}$ olan dEFKY hastalarında SV kullanımıyla ilgili elimizde yeterince kanıt yoktur. Bununla birlikte, SV ile elde edilen gerçek yaşam verilerine, ${ }^{[21]} \mathrm{ACEI} / \mathrm{ARB}$ ile yapilan randomize olmayan prospektif çalışmalara ${ }^{[4]}$ ve KY olmayan KBH'ında (\%38'inde GFR <30 ml/dk idi) SV'nın irbesartan ile karşılaştırıldı $\breve{1}$ UK Heart and Renal Protection (HARP)-III çalışmasının sonuçlarına ${ }^{[22]}$ bakarak GFR $<30 \mathrm{ml} / \mathrm{dk}$ olan hastalarda SV yönetimi hakkında yorum yapılabilir. tGFR değeri $<30 \mathrm{ml} / \mathrm{dk}$ olan dEFKY hastalarına da endikasyonları karşılıyor ise yakın takip ile (hergün BFT bakarak) SV verilebilir. Böbrek fonksiyonları sakubitril konsantrasyonu için asıl belirleyicidir ve GFR'deki her $10 \mathrm{~mL} / \mathrm{dk}$ düşüş ile sa- kubitril konsantrasyonunda 1485 (572-2397) ng/mL artış olmaktadır. ${ }^{[21]}$ Dolayısıyla bu hastaların kan basıncı müsait olsa bile SV'nı en düşük dozda (günde iki doz 24/26 mg) başlanmak daha güvenli bir yaklaŞım olacaktır. Tedaviye başladıktan sonra Şekil 1 ve 2 'deki algoritmalara benzer biçimde ilerleyerek SV tolere edilen doza yükseltmeye çalışılmalıdır. Ancak çoğunlukla en fazla günden iki doz 49/51 mg'a çık1labilmektedir. ${ }^{[23]}$

\section{Kaynaklar}

1. Campbell RC, Sui X, Filippatos G, Love TE, Wahle C, Sanders PW, et al. Association of chronic kidney disease with outcomes in chronic heart failure: a propensity-matched study. Nephrol Dial Transplant 2009;24:186-93.

2. Ouwerkerk W, Voors AA, Anker SD, Cleland JG, Dickstein K, Filippatos G, et al. Determinants and clinical outcome of uptitration of ACE-inhibitors and beta-blockers in patients with heart failure: a prospective European study. Eur Heart J 2017;38:1883-90.

3. Ponikowski P, Voors AA, Anker SD, Bueno H, Cleland JGF, Coats AJS, et al. 2016 ESC Guidelines for the diagnosis and treatment of acute and chronic heart failure: The Task Force for the diagnosis and treatment of acute and chronic heart failure of the European Society of Cardiology (ESC) Developed with the special contribution of the Heart Failure Association (HFA) of the ESC. Eur Heart J 2016;37:2129-200.

4. Edner M, Benson 1, Dahlström U, Lund LH. Association between renin-angiotensin system antagonist use and mortality in heart failure with severe renal insufficiency: a prospective propensity score-matched cohort study. Eur Heart J 2015;36:2318-26.

5. McMurray JJ, Packer M, Desai AS, Gong J, Lefkowitz MP, Rizkala AR, et al. Angiotensin-neprilysin inhibition versus enalapril in heart failure. N Engl J Med 2014;371:993-1004.

6. Desai AS, Vardeny O, Claggett B, McMurray JJ, Packer M, Swedberg $\mathrm{K}$, et al. Reduced Risk of Hyperkalemia During Treatment of Heart Failure With Mineralocorticoid Receptor Antagonists by Use of Sacubitril/Valsartan Compared With Enalapril: A Secondary Analysis of the PARADIGM-HF Trial. JAMA Cardiol 2017;2:79-85.

7. Packer M, Claggett B, Lefkowitz MP, McMurray JJV, Rouleau JL, Solomon SD, et al. Effect of neprilysin inhibition on renal function in patients with type 2 diabetes and chronic heart failure who are receiving target doses of inhibitors of the renin-angiotensin system: a secondary analysis of the PARADIGM-HF trial. Lancet Diabetes Endocrinol 2018;6:547-54.

8. Damman K, Gori M, Claggett B, Jhund PS, Senni M, Lefkowitz MP, et al. Renal effects and associated outcomes during angiotensin-neprilysin inhibition in heart failure. JACC Heart Fail 2018;6:489-98.

9. McMurray J, Seidelin PH, Howey JE, Balfour DJ, Struthers AD. The effect of atrial natriuretic factor on urinary albumin and beta 2-microglobulin excretion in man. J Hypertens 1988;6:783-6.

10. Axelsson J, Rippe A, Rippe B. Transient and sustained increases in glomerular permeability following ANP infusion in rats. Am J Physiol Renal Physiol 2011;300:F24-30.

11. National Kidney Foundation. KDIGO 2012 Clinical Practice Guideline for the Evaluation and Management of Chronic Kidney Disease. Availabla at: https://kdigo.org/wp-content/uploads/2017/02/KDIGO_2012_CKD_GL.pdf. Accessed Jun 15, 2020.

12. House AA, Wanner C, Sarnak MJ, Pina IL, McIntyre CW, Komenda $\mathrm{P}$, et al. Heart failure in chronic kidney disease: conclusions from a Kidney Disease: Improving Global Outcomes (KDIGO) Controversies Conference. Kidney international 2019;95:1304-17. 
13. Mullens W, Daman K, Testani JM, Martens P, Mueller C, et al. Johan LassusEvaluation of kidney function throughout the heart failure trajectory - a position statement from the Heart Failure Association of the European Society of Cardiology. Eur J Heart Fail 2020;22:584603.

14. Çavuşoğlu Y, Altay H, Ekmekçi A, Eren M, Küçükoğlu MS, Nalbantgil S, et al. Practical approaches for the treatment of chronic heart failure: Frequently asked questions, overlooked points and controversial issues in current clinical practice. Anatol J Cardiol 2015:15;1-60.

15. Pannu N, Nadim MK. An overview of drug-induced acute kidney injury. Crit Care Med 2008;36:S216-S23.

16. Yancy CW, Jessup M, Bozkurt B, Butler J, Casey DE, Drazner MH, et al. 2013 ACCF/AHA Guideline for the Management of Heart Failure. J Am Coll Cardiol 2013;62:e147-239.

17. Ahmed MI, Ekundayo OJ, Mujib M, Campbell RC, Sanders PW, Pitt B, et al. Mild hyperkalemia and outcomes in chronic heart failure: A propensity matched study. Int J Cardiol 2010:144;383-8.

18. Wei L, Struthers AD, Fahey T, Watson AD, MacDonald TM. Spironolactone use and renal toxicity: population based longitudinal analysis. BMJ 2010;340:c1768.
19. Agarwal R, Rossignol P, Romero A, Garza D, Mayo MR, Warren S, et al. Patiromer versus placebo to enable spironolactone use in patients with resistant hypertension and chronic kidney disease (AMBER): a phase 2, randomised, double-blind, placebo-controlled trial. Lancet 2019;394:1540-50.

20. Laflamme É, Vachon A, Gilbert S, Boisvert J, Leclerc V, Bernier M, et al. Usefulness of a titration algorithm for de novo users of sacubitril/valsartan in a tertiary centre heart failure clinic. Cardiovasc J Afr 2018;29:352-6.

21. Chang HY, Feng AN, Fong MC, Hsueh CW, Lai WT, Huang KC, et al. Sacubitril/valsartan in heart failure with reduced ejection fraction patients: Real world experience on advanced chronic kidney disease, hypotension, and dose escalation. J Cardiol 2019;74:37280.

22. Haynes R, Judge PK, Staplin N, Herrington WG, Storey BC, Bethel A, et al. Effects of sacubitril/valsartan versus irbesartan in patients with chronic kidney disease. Circulation 2018;138:1505-14.

23. Quiroga B, de Santos A, Sapiencia D, Saharaui Y, Álvarez-chiva V. Sacubitril/valsartan in chronic kidney disease, the nephrologist point of view. Nefrologia 2019;39:646-52. 